\title{
European Court of Human Rights Case Law on Genetic Information in the Scope of International Biomedical Law
}

Knowledge about genetic data - as a biological determinant of the psychophysical characteristics of a human being, and which is linked to the development of human genome mapping programmes - raises questions about the direction of legal policy in the field of international biomedical law and domestic legal systems. These issues are also addressed in the case law of the European Court of Human Rights. ${ }^{1}$ Through the application of its dynamic approach to the interpretation of the Convention on Human Rights and Fundamental Freedoms, the Court has begun to outline a new perception of the right to respect for privacy which enables the protection of human genetic data. Bearing this in mind, the aim of this paper is to analyze the European Court of Human Rights' case law on genetic information in the scope of international biomedical standards expressed in both the International Declaration on Human Genetic Data and the Convention on the Protection of Human Rights and Human Dignity in the Field of Application of Biology and Medicine.

\section{International Standards for the Protection of Genetic Data}

International standards for the protection of genetic data are reflected in the provisions of the International Declaration on Human Genetic

1 Hereinafter: the European Court of Human Rights or the Court. 
Data adopted at UNESCO's General Conference on the 16th of October $2003^{2}$, and the Convention for the protection of Human Rights and Dignity of the Human Being with regard to the Application of Biology and Medicine adopted by on the 4th of April 1997. ${ }^{3}$

The International Declaration on Human Genetic Data regulates "the collection, processing, use and storage of human genetic data, human proteomic data and of the biological samples from which they are derived in keeping with the requirements of equality, justice and solidarity, while giving due consideration to freedom of thought and expression, including freedom of research." ${ }^{4}$ By granting a special status to human genetic data, the Declaration emphasises its characteristics, which consist of the following: the ability to define individuals' genetic predispositions, the ability to influence human offspring, a cultural dimension, and a special status since these data may contain information whose significance only becomes apparent as a result of a genetic test. For these reasons, the Declaration calls upon the international community to protect both genetic data and the biological samples from which the said data are derived, and establishes provisions to define the purposes and procedures for its collection, processing, use and storage. In particular, these provisions cover diagnostics, health care, scientific research, forensic medicine and legal proceedings. The Declaration also allows for other purposes of collection, processing, use and storage than those enumerated in its text, establishing a condition of compliance with its provisions and the international human rights system. Those exceptional purposes and procedures relating to the use of human genetic data and proteomic data must comply with ethical standards, and the policy pursued in this respect should take into account the views expressed by

2 The International Declaration on Human Genetic Data, adopted by the General Conference of UNESCO on 16 October 2003, SHS/EST/BIO/06/1. Hereinafter: DHGD.

3 Convention for the Protection of Human Rights and Dignity of the Human Being with regard to the Application of Biology and Medicine adopted on the 4th of April 1997, CETS no.164. Hereinafter: CHRB.

4 Art. 1. DHGD. 
society. Ethical committees play an important role in this policy: these institutions - operating at national, regional, local and institutional levels - have been assigned the role of consultants to express their opinions in the process of regulating the handling and use of human genetic, proteomic and biological data in specific projects.

The condition for taking actions involving human genetic data is the consent of the person concerned. This consent must be expressed in an informed, voluntary and direct manner, after the person has been informed of the purpose of the collection, processing, use and storage of the data, the consequences associated with these activities, and the possibility of withdrawing consent at any stage of the procedure. Following the model of the Universal Declaration on the Human Genome and Human Rights ${ }^{5}$, the International Declaration on Human Genetic Data also allows for an exception to this principle, involving reasons of major importance to the health of the person concerned, in the absence of the ability to give informed consent. The Declaration states that this interference shall be determined by national law and must be in accordance with the international system for the protection of human rights, while taking into account the overriding nature of the interests of the individual. These are the right to decide whether or not to receive information on test results, and the right to seek professional advice when considering the possibility of undergoing genetic testing. In principle, it is therefore prohibited to deny an individual access to their own data. However, this condition does not apply in the case of an irreversible disconnection from an identifiable source, or circumstances constituting a threat to national health, public order or security.

The Declaration obliges States to take steps to protect the privacy of genetic data by establishing domestic laws that are compatible with the international human rights system. In this context, it formulates a set of directives which encompass:

5 The Universal Declaration on the Human Genome and Human Rights adopted by the General Assembly on the 11th Of November 1997, A/Res/53/152. 
- a prohibition on disclosing human genetic data, proteomic data or biological samples linked to an identifiable person to third parties, or rendering these data or samples accessible to them ${ }^{6}$,

- the requirement not to link human genetic data, proteomic data or biological samples collected for scientific research purposes to an identifiable person, with the exception of cases where this is essential for the nature of the research, while simultaneously ensuring the protection of the privacy of these data and restricting their period of storage to the essential minimum ${ }^{7}$,

- the requirement for persons and organizational units responsible for the processing of both data and biological samples to ensure their accuracy, credibility, security and quality. ${ }^{8}$

The framework of international cooperation in the field of the circulation of human genetic data, proteomic data and biological samples is specified in the following requirements:

- the requirement for States to regulate the circulation of human genetic data, proteomic data and biological samples in accordance with domestic and international legislation, and in a manner ensuring fair access to these data ${ }^{9}$,

- the requirement for States to make every effort with regard to fostering the international dissemination of scientific knowledge related to human genetic data and proteomic data ${ }^{10}$,

- the requirement for scientists to make every effort towards establishing collaboration with regard to human genetic data and proteomic data, subject to the restrictions expressed in this Declaration. ${ }^{11}$

6 Art. 14 (b) DHGD.

7 Art. 14 (c) (d) DHGD.

8 Art. 15. DHGD.

9 Art. 18 (a) DHGD.

10 Art. 14 (b) DHGD.

11 Art. 14 (c) DHGD. 
This cooperation is linked to the obligation to share the results of scientific research using human genetic, proteomic and biological data with both citizens and the international community, subject to the restrictions laid down by national legislation and international agreements. Examples of ways of achieving this cooperation ${ }^{12}$ are:

- establishing forms of special assistance provided to individual persons and groups participating in the research;

- guaranteeing access to medical care;

- using the research results to ensure new diagnostic methods, means of treatment, and medicines;

- providing support for health services;

- providing research assistance for developing countries;

- other forms of action in keeping with the principles of this Declaration.

Selected provisions of the Convention on the Protection of Human Rights and Human Dignity in the Field of Application of Biology and Medicine ${ }^{13}$, which regulates the relationship between human rights and the practical dimension of the functioning of biological and medical sciences ${ }^{14}$, are devoted to genetic data. This Convention protects human genetic data by distinguishing health information connected with the right to respect for private life and the right to information. Within the scope of the latter, the Convention provides human genome protection that combines: a prohibition of genetic discrimination, certain restrictions on genetic testing, cer-

12 Art. 19 DHGD.

13 V. CHRB; M. Grzymkowska, Standardy bioetyczne w prawie europejskim, Warszawa 2009; A. Krajewska, Informacja genetyczna a zakres autonomii jednostki w europejskiej przestrzeni prawnej, Wrocław 2008; O. Nawrot, Ludzka biogeneza w standardach bioetycznych Rady Europy, Warszawa 2011, J. Symonides, Międzynarodowe instrumenty prawne $w$ dziedzinie bioetyki i biotechnologii, in: Prawa człowieka wobec rozwoju biotechnologii, ed. L. Kondratiewa-Bryzik, K. Sękowska-Kozłowska, Warszawa 2013, p. 30.

14 The Convention regulates consent for an intervention in the health field, private life and right to information, human genome, scientific research, organ and tissue removal from living donors for transplantation purposes and the prohibition of financial gain and the disposal of a part of the human body. 
tain restrictions on intervention in the human genome, and a prohibition on using techniques of medically assisted procreation for the purpose of sex selection, except in the case of serious hereditary sex-related disease.

\section{Genetic Data Protection in the Scope of the Interpretation of Article 8 of the Convention on Human Rights and Fundamental Freedoms}

There are echoes of violations that come from the practical dimension of the biomedical sciences in the individual applications directed to the Court. In considering the allegations raised in them, the Court has interpreted the provisions of the Convention, guided by the dynamics of changes taking place in the modern social structure. Those changes cover: reproductive rights ${ }^{15}$, medically assisted procreation $^{16}$, surrogate motherhood ${ }^{17}$, euthanasia ${ }^{18}$, consent to be treated ${ }^{19}$,

15 The authors of the research report on Bioethics and the case-law of the Court lists the following examples of case-law on reproductive rights: Draon v. France, no. 1513/03, judgment of 6 October 2005; D. v. Ireland, no. 26499/02, decision of 27 June 2006; Tysiąc v. Poland, no. 5410/03, judgment of 20 March 2007.

16 The authors of the research report on Bioethics and the case-law of the Court lists the following examples of case-law on medically assisted procreation: Evans v. the United Kingdom, no. 6339/05, judgment of 10 April 2007; Dickson v. the United Kingdom, no. 44362/04, judgment of 4 December 2007; S.H and Others v. Austria, no. 57813/00, judgment of 3 November 2011.

17 The authors of the research report on Bioethics and the case-law of the Court lists the following examples of case-law on surrogate motherhood: D. and Others v. Belgium, no. 29176/13, decision of 8 July 2014; Mennesson v. France, no. 65192/11, judgment of 26 June 2014 and Labassee v. France, no. 65941/11, judgment of 26 June 2014; Foulon and Bouvet v. France, no. 9063/14 and 10410/14, judgment of 21 July 2016; Paradiso and Campanelli v. Italy, no. 25358/12, judgment of 27 January 2015.

18 The authors of the research report on Bioethics and the case-law of the Court lists the following examples of euthanasia case-law: Koch v Germany, no. 497/09, judgment of 19 July 2012; Gross v. Switzerland, no. 67810/10, judgment of 30 September 2014.

19 The authors of the research report on Bioethics and the case-law of the Court lists the following examples of case-law on a consent to be treated: Glass v. the United Kingdom, no. 61827/00, judgment of 9 March 2004; Jalloh v. Germany, no. 54810/00, judgment of 11 July 2006; M.A.K. and R.K. v. the United Kingdom, no. 45901/05 and 40146/06, judgment of 23 March 2010. 
transgender ${ }^{20}$, storage of fingerprints, biological data and genetic profile ${ }^{21}$, as well as biological identity. ${ }^{22}$ When examining the selected cases, the Court pays attention to the right to life, the prohibition of torture, the right to liberty and security, the right to a fair trial, the right to respect for private and family life, the prohibition of discrimination and the protection of property, by reinterpreting the meaning of Articles 2, 3, 5, 6, 8, 14 of the Convention and Article 1 of its first Protocol.

Article 8 of the Convention for the Protection of Human Rights and Fundamental Freedoms ${ }^{23}$ guarantees the right to respect for the private spheres of life by protecting individuals from arbitrary interference from the State authorities. The Convention divides the private sphere of life into four categories, by distinguishing: private life, family life, home and correspondence. The article is composed of two paragraphs. The first one guarantees to everyone "the right to respect for his private and family life, his home and his correspondence.”24 The second is regarded as a limitation clause and states that" there shall be no interference by a public authority with the exercise of this right except such as is in accordance with the law and is necessary in a democratic society in the interests of national security, public safety or the economic well-being of the country, for the prevention of disorder or crime, for the protection of health or morals, or for the protection of the rights and freedoms of others."25

20 The authors of the research report on Bioethics and the case-law of the Court lists the following examples of case-law on transgender: Y.Y. v. Turkey, no. 14793/08, judgment of 10 March 2015.

21 The authors of the research report on Bioethics and the case-law of the Court lists the following examples of case-law on storage of fingerprints, biological data and genetic profile: S. and Marper v. United Kingdom, no. 30562/04 and 30566/04, judgement of 4 December 2008.

22 The authors of the research report on Bioethics and the case-law of the Court lists the following examples of case-law on biological identity: Jäggi v. Switzerland, no. 58757/00, judgment of 13 July 2006.

Phinikaridou v. Cyprus, no. 23890/02, judgment of 20 December 2007; Darmon v. Poland, no. 7802/05, decision of 17 November 2009; Gronmark v. Finland, no. 17038/04, judgment of 6 July 2010; Backlund v. Finland, no. 36498/05, judgment of 6 July 2010.

23 Convention for the Protection of Human Rights and Fundamental Freedoms adopted 4 November 1950, ETS 5, 213 UNTS 222, Hereinafter: ECHR.

24 Art. 8 (1) ECHR.

25 Art. 8 (2) ECHR. 
The way in which the distinguished areas are interpreted determines the content of the rights guaranteed under Article 8 of the Convention. ${ }^{26}$ The first of the selected categories - private life - escapes the definitional framework. From this reason the Court reconstructs the meaning of a private life, by identifying cases that fall within its scope. This activity involves a dynamic approach to the interpretation of the Convention, which allows for the possibility of extending the scope of protection granted to the sphere of private life. Its framework is subordinated to the idea of the psychophysical integrity of the human person, accompanied by a guarantee of individual autonomy. This idea is implemented in:

- the protection of personal identity: name, origin, gender and sexual orientation

- the prohibition of discrimination ${ }^{27}$,

- the prohibition of the arbitrary interference in physical, psychological and moral integrity ${ }^{28}$,

- the protection of honour and reputation ${ }^{29}$,

- standards of data and information protection ${ }^{30}$,

- the right to the environment. ${ }^{31}$

The second of the selected spheres of personal autonomy concerns the family. ${ }^{32}$ The relationship between family members in their social, cultural, moral and material status is protected by the Convention. ${ }^{33}$ The notion of the family applies to both formally established ties and factual relationships. ${ }^{34}$ Family life covers three fields of interpersonal relations.

26 W. Schabas, The European Convention on Human Rights. A Commentary, New York 2017, pp. 369-388.

27 L. Garlicki, Komentarz do art. 8, in: Konwencja o Ochronie Praw Człowieka i Podstawowych Wolności. Komentarz do artykułów 1-18, ed. L. Garlicki, I, Warszawa 2010, pp. 493-499.

28 Ibidem, pp. 499-500.

29 Ibidem, pp. 500-506.

30 Ibidem, pp. 506-507.

31 Ibidem, pp. 508-518.

32 W. Schabas, The European Convention..., pp. 388-400.

33 Merger and Cros v. France, no. 68864/01, judgement of 22 December 2004.

34 Marckx v. Belgium, no. 6833/74, judgement of 13 June 1979. 
The first one concerns marriage. The second is related to the relationship between parents and children. The third, in turn, includes situations of special subordination, concerning persons deprived of their liberty and foreigners. Besides respect for private and family life, Article 8 of the Convention protects the home and correspondence. ${ }^{35}$ The term 'home' is interpreted within the scope of the term domicile used in the French version of the Convention. ${ }^{36}$ Under this interpretation, Article 8 protects not only the physical place of residence where an individual conducts their private or family life, but also professional and commercial premises. Both natural and legal persons are entitled to exercise the right to respect for their "home", which extends to the protection of correspondence as well. The concept of correspondence covers both electronic and traditional forms of mail. The case law of the European Court of Human Rights illustrates what the term correspondence is intended to cover:

- traditional forms of mail communication ${ }^{37}$,

- the technical form of text messages ${ }^{38}$,

- forms of sending messages via private devices ${ }^{39}$,

- forms of sending messages via public devices ${ }^{40}$,

- the sending of messages by a person subject to an extraordinary form of subordination. ${ }^{41}$

The case law of the European Court of Human Rights stipulates the meaning of the selected forms of communication and enumerates the list of restrictions allowed by the Convention that can be imposed by public authorities.

35 W. Schabas, The European Convention on Human Rights. A Commentary, New York 2017, pp. 400-401.

36 L. Garlicki, Komentarz do art. 8, in: Konwencja o Ochronie Praw Człowieka i Podstawowych Wolności. Komentarz do artykułów 1-18, ed. L. Garlicki, I, Warszawa 2010, p. 537.

37 Ibidem, s. 542.

38 Weber and Saravia v. Germany, no. 54934/00, decision of 29 June 2006.

39 Halford v. United Kingdom, no. 20605/92, judgement of 25 June 1997.

40 Ibidem.

41 Golder v. United Kingdom, no. 4451/70, judgement of 21 February 1975. 
Analysing the scope of right to respect for private and family life, Marek Antoni Nowicki points out that protection of individuals from arbitrary interference combines both negative and positive dimensions of the obligation. ${ }^{42}$ The former concerns the prohibition of actions that might violate human autonomy. The latter obliges States Parties to the Convention to establish the means to protect individuals' private lives. This positive dimension of the obligation is implied by the nature of the distinguished spheres of private life, the individual's position, and the State's practice that shapes its context. Its analysis is determined by the rule of law principle. ${ }^{43}$ The status of the Convention as a living instrument ${ }^{44}$ allows for a dynamic approach to the interpretation of its provisions in judicial practice, which makes extending the meaning of the right to respect for private and family life possible. This interpretation is in compliance with the set of conditions expressed in the Judgment of the Court of 7 December 1976 in the Case of Handyside v. United Kingdom. ${ }^{45}$ These conditions demand a special protection of the rights guaranteed by the provisions of Articles 8,9,10 and 11 of the Convention, justified by their fundamental role for the functioning of democratic society. ${ }^{46}$ With this justification comes the necessity ascribing certain limitations to the forms of interference. These are related to the exceptional status of these actions, which might be used only on a particular occasion. As William Schabas points out: "the definition of the right in the first paragraph of Article 8 is complemented by a second paragraph that restricts or limits the scope of the right." 47 "In its application of Article 8, the Court first proceeds to consider whether there has been an interference with a right within the scope of paragraph 1 . It then, as a general rule examines the criteria set out in paragraph 2 in

42 M.A. Nowicki, Wokół Konwencji Europejskiej. Komentarz do Europejskiej Konwencji Praw Człowieka, Warszawa 2017.

43 Ibidem.

44 Tyrer v. United Kingdom, no. 5856/72, judgement of 2 April 1978, § 73.

45 Handyside v. United Kingdom, no. 5493/72, judgement of 7 December 1976.

46 Ibidem.

47 W. Schabas, The European Convention..., p. 367. 
order to determine whether the interference is also the violation of the Convention", ${ }^{48}$ When examining the selected premises, the Court answers the question of whether interference was in accordance with law and necessary in a democratic society. The objective of the first clause is to consider whether interference is authorized by a rule recognized in the national legal order, accessible and foreseeable and "subject to mechanisms so that it can be applied to in a manner that is genuine and not arbitrary." ${ }^{49}$ The objective of the second clause it to "consider whether the authorities have struck 'a fair balance between the competing interests of the individual and of society as a whole"50."51

To reconstruct the meaning and scope of the application of genetic data protection it is necessary to pay attention to the element of Article 8 of the Convention which guarantees the respect for private life. The Court analyzed this in the decision in the Van der Velden v. Netherlands case of 7 December $2006^{52}$ and the Judgement in the $S$. and Marper v. United Kingdom case from 4 December 2008. ${ }^{53}$ In declaring the inadmissibility of the Van der Velden application, the Court held that the collection of biological samples and human genetic data of a convicted person could not be regarded as a form of criminal penalty under Article 7 of the Convention. This view is supported by the observations on the possibility of limiting the right to data protection of a convicted person in the case of crimes of a certain degree of seriousness, when establishing general principles of collecting biological samples in order to determine a genetic profile. The Court was of the opinion that if such interference to be allowed, must be - interpreted within the scope of Article 8 of the Convention - "in accordance with law" and "necessary in a democratic society”.

48 Ibidem, p. 367.

49 Ibidem, p. 403.

50 Keegan v. Ireland, no. 16969/90, Judgement of 26 May 1994.

51 W. Schabas, The European Convention..., p. 406.

52 Van der Velden v. Netherlands, no. 29514/05, decision of 7 December 2006.

53 S. and Marper v. United Kingdom, no. 30562/04 and 30566/04, judgement of 4 December 2008. 
The Court's declaration expressed in the Van der Velden case is reflected in its case law. When considering S. and Marper v. United Kingdom, the Court paid attention to the regulations concerning storing fingerprint samples and DNA profiles. ${ }^{54}$ Holding that there had been a violation of Article 8 of the Convention, the Grand Chamber of the Court confirmed that genetic data protection falls within the scope of application of the right to respect for private life. According to the issued judgment, the storage of these data after the end of criminal proceedings by an acquittal or remission violates the right guaranteed in Art. 8 of the Convention.

In 2001 Mr. S. and Mr. Marper were accused of committing crimes. Mr. S. was charged with attempted robbery, while Mr. Marper was charged with harassment of his partner. Both applicants' fingerprints and DNA samples were taken during the criminal proceedings. The first case ended with a judgment of acquittal. In the second one the Crown Prosecution Service served a notice of discontinuance. After the proceedings had ended, both applicants asked for their fingerprints and DNA samples to be destroyed. Both applications were refused, so the applicants applied for a judicial review. On the 22 March 2002 the Administrative Court rejected the application. Its judgement was confirmed by the Court of Appeal and then two years later by the House of Lords. The justification for the refusal comes with the interpretation of Article $64(1 \mathrm{~A})$ of the Police and Criminal Evidence Act of $1984^{55}$, which regulates the storage of biological samples and fingerprints after the criminal procedure is over. The Police and Criminal Evidence Act of 1984 allows the storage

54 There are several comments on the Judgement in the S. and Marper v. United Kingdom case in the legal scholarly papers: L. Heffernan, DNA and fingerprint data retention: S and Marper v UK, “European Law Review” 2009, no. 34(3), pp. 491-504; J. Kapelańska-Pręgowska, Informacja genetyczna jako kategoria chronionych danych osobowych. Uwagi na tle orzecznictwa Europejskiego Trybunału Praw Człowieka, in: Między wykładniq a tworzeniem prawa. Refleksje na tle orzecznictwa Europejskiego Trybunału Praw Człowieka i międzynarodowych trybunałów karnych, eds C. Mik, M. Gałka, Toruń 2011; A. Peterson, S. And Marper v. United Kingdom: the European Court of Human Rights Overturs the UK’s Procedure for the Indefinite Retention of Unconvicted Person's Personal Data, "Tulane Journal of International \& Comparative Law” 2010, vol. 18, issue 2, pp. 557-572.

55 Police and Criminal Evidence Act of 1984, 1984 p. 60. 
of fingerprints and DNA samples in the database of the investigative bodies for the purpose of prevention, detection, preparatory proceedings and prosecution, even if the aim for which they were obtained has already been achieved and the criminal procedure has been completed. The application of Article 64 (1A) of the Police and Criminal Evidence Act also covered the samples of Mr. S. and Mr. Marper.

The applicants filed complaints under Articles 8 and 14 of the Convention, alleging that the authorities had interfered with their right to respect for private and family life by continuing to retain their fingerprints and DNA profiles in an unjustified way, which could be regarded as a form of discrimination. In its reply to applications 30562/04 and 30566/04, the United Kingdom recalled the public interest that the Police and Criminal Evidence Act of 1984 serves. When examining the applications, however, the Court decided that there had been a violation of Article 8 of the Convention. The Court held that it was not necessary to examine the complaint under Article 14 of the Convention separately. The Court's conclusion was as follows:

The blanket and indiscriminate nature of the powers of retention of the fingerprints, cellular samples and DNA profiles of persons suspected but not convicted of offences, as applied in the case of the present applicants, fails to strike a fair balance between the competing public and private interests and that the respondent State has overstepped any acceptable margin of appreciation in this regard. Accordingly, the retention at issue constitutes a disproportionate interference with the applicants' right to respect for private life and cannot be regarded as necessary in a democratic society. ${ }^{56}$

In its assessment, the Court made a distinction between cellular samples containing genetic data and fingerprints. The concept of the protection of genetic information analyzed within the scope of the application of

56 S. and Marper v. United Kingdom, no. 30562/04 and 30566/04, judgement of 4 December 2008. 
Article 8 of the Convention leads to an argument devoted to the issue of genetic data. In this regard, in order to determine whether there had been a violation of the right guaranteed in Article 8 of the Convention, the Court emphasized the importance of the individual's concerns about the potential future use of this data. The Court emphasized the role of personal data that is stored in a cellular sample, indicating that its storage constitutes an interference with private life. This must be examined within the scope of the broader perspective, referring not only to the donor of the biological material, but also to persons with a genetic relationship with them. Furthermore, the Court noted that information about a person's ethnicity can be determined from genetic data. For these reasons the Grand Chamber of the Court drew the conclusion that the storage of genetic data needs to meet the requirement of proportionality and be subjected to a time regime restriction.

The conception of genetic data protection was developed in the case law of the European Court of Human Rights in the Van der Velden v. The Netherlands and S. and Marper v. The United Kingdom cases. In the scope of that interpretation, the aim of Article 8 is to protect both genetic data and biological samples that allow the donor's profile to be known. When examining applications, the Court focuses on both formal and material premises to assess if the conduct of the public authorities interferes the sphere of private life. If interference is identified, the next step is to examine if it is "in accordance with law" and "necessary in a democratic society". The Court assumes that the Convention allows such interference when it finds its justification in the goal of the criminal proceedings or the DNA profile database, noting the necessity of a time regime restriction.

In determining the scope of protection of genetic data, the Court interprets Article 8 of the Convention through a comparative juxtaposition of standards of international human rights law ${ }^{57}$, European Union

57 The European Court of Human Rights recalls both regional and universal standards of international law: United Nations Convention on the Rights of the Child of 1989, United Nations 
$\mathrm{law}^{58}$, the national law of Member States ${ }^{59}$, and the case law of the Supreme Court of Canada. ${ }^{60}$ The first point of the comparison focuses on Article 40 of the United Nations Convention on the Rights of the Child, The Council of Europe Convention of 1981 for the protection of individuals with regard to automatic processing of personal data, Recommendation No. R (87) 15 of the Committee of Ministers regulating the use of personal data in the police sector and Recommendation No. R (92) 1 of the Committee of Ministers on the use of analysis of deoxyribonucleic acid (DNA) within the framework of the criminal justice system. The second draws on Directive 95/46/EC of the European Parliament and of the Council of 24 October 1995 on the protection of individuals with regard to the processing of personal data and on the free movement of such data. The third concerns the regulation of the use of genetic data in criminal proceedings of selected Member States of the Council of Europe. Lastly, the fourth considers the decision in R v. R. C., in which the Supreme Court of Canada ruled that the storage of a minor's genetic data in a DNA database was unduly intrusive and stressed the disproportionate nature of such a measure. In this comparative overview, however, the Court does not refer to the provisions of the International Declaration on Human Genetic Data or to the Convention for the Protection of Human Rights and Dignity of the Human Being with regard to the Application of Biology and Medicine. Thus, any attempt to assess the way in which the protection of genetic data is defined in terms of the biomedical stan-

Treaty Series, vol. 1577, p. 3; The Council of Europe Convention of 1981 for the protection of individuals with regard to automatic processing of personal data, ETS no. 108, 28.01.1981; Recommendation no. R (87) 15 of the Committee of Ministers regulating the use of personal data in the police sector and Recommendation no. R (92) 1 of the Committee of Ministers on the use of analysis of deoxyribonucleic acid DNA within the framework of the criminal justice system.

58 Directive 95/46/EC of 24 October 1995 on the protection of individuals with regard to the processing of personal data and on the free movement of such data provides that the object of national laws on the processing of personal data, Official Journal L 281, 23/11/1995 P. 0031-0050.

59 The European Court of Human Rights lists the following examples of states with a limited DNA taking procedures: Austria, Belgium, Finland, France, Germany, Hungary, Ireland, Italy, Luxembourg, the Netherlands, Norway, Poland, Spain and Sweden.

60 R. v. R.C., [2005] 3 S.C.R. 99, 2005 SCC 61 
dards encoded in these documents requires a separate analysis. The International Declaration on Human Genetic Data lists forensic medicine and civil, criminal and other legal proceedings as the valid purposes for collecting, processing, using and storing human genetic data. ${ }^{61}$ The Declaration links the collection of biological samples "for the purposes of forensic medicine or in civil, criminal and other legal proceedings" to the requirements of domestic law that are consistent with the international human rights law. ${ }^{62}$ The declaration also regulates, in an analogous way, the storage of biological samples which are used to obtain genetic data during ongoing proceedings. ${ }^{63}$ Human genetic data, proteomic data and biological samples can be made available for forensic medicine and civil proceedings only until the end of the proceedings, unless otherwise provided by domestic law consistent with international human rights law. ${ }^{64}$ Although those provisions were not cited in the Marper and S. v. United Kingdom judgment, the Court relies on a comparison between the legal system of the United Kingdom and the examples of legislation in force in the Member States of the Council of Europe in order to demonstrate the extent to which DNA databases in the UK fall short of the standards laid down for the protection of personal data. The Court observes that these regulations introduce restrictions on the collection of genetic data which are lacking in the British legal system. The Court also draws attention to the status of genetic information, and the position it adopts in this respect corresponds with the way genetic data is characterised in the International Declaration on Human Genetic Data, which draws attention to the possibilities of the use of genetic data in the future that are linked to the development of human genome mapping programmes. ${ }^{65}$ Indeed, these data serve not only to identify and single out individuals, but also constitute a source of health information that 
remains under the protection of Article 11 of the Convention for the Protection of Human Rights and Dignity of the Human Being with regard to the Application of Biology and Medicine. ${ }^{66}$

The conception of genetic data protection was developed in the case law of the European Court of Human Rights in the Van der Velden v. The Netherlands and S. and Marper v. The United Kingdom cases. In its scope, the aim of Article 8 is to protect both genetic data and biological samples that allow the donor's profile to be known. When examining applications, the Court focuses on both formal and material premises to assess if the public authorities' conduct interferes the sphere of private life. If interference is identified, the next step is to examine if it is "in accordance with law" and "necessary in a democratic society". The Court assumes that the Convention allows such interference when it finds its justification in the goal of the criminal proceedings or the DNA profile database, noting the necessity of a time regime restriction. Although the Court does not explicitly cite the provisions of International Declaration on Human Genetic Data or the Convention for the Protection of Human Rights and Dignity of the Human Being with regard to the Application of Biology and Medicine, its position can be seen to be compatible with with the norms of international biomedical law encoded in these documents. These provisions leave the states of the international community a margin of discretion in regulating the method of taking biological samples, storing genetic data, and destroying biological samples, while ensuring that information about health remains a part of private life. The limits of this freedom are to be determined by international law.

66 Art. 11 CHRB. 


\section{References}

Garlicki L., Komentarz do art. 8, in: Konwencja o Ochronie Praw Człowieka i Podstawowych Wolności. Komentarz do artykułów 1-18, ed. L. Garlicki, I, Warszawa 2010.

Grzymkowska M., Standardy bioetyczne w prawie europejskim, Warszawa 2009.

Heffernan L., DNA and fingerprint data retention: $S$ and Marper v UK, "European Law Review” 2009, no. 34(3).

Kapelańska-Pręgowska J., Informacja genetyczna jako kategoria chronionych danych osobowych. Uwagi na tle orzecznictwa Europejskiego Trybunału Praw Człowieka, in: Między wykładniq a tworzeniem prawa. Refleksje na tle orzecznictwa Europejskiego Trybunału Praw Człowieka i międzynarodowych trybunałów karnych, eds C. Mik, M. Gałka, Toruń 2011.

Krajewska A., Informacja genetyczna a zakres autonomii jednostki w europejskiej przestrzeni prawnej, Wrocław 2008.

Nawrot O., Ludzka biogeneza w standardach bioetycznych Rady Europy, Warszawa 2011.

Peterson A., S. And Marper v. United Kingdom: the European Court of Human Rights Overturs the UK's Procedure for the Indefinite Retention of Unconvicted Person's Personal Data, "Tulane Journal of International \& Comparative Law” 2010, vol. 18, issue 2.

Schabas W., The European Convention on Human Rights. A Commentary, New York 2017.

Symonides J., Międzynarodowe instrumenty prawne w dziedzinie bioetyki i biotechnologii, [in:] Prawa człowieka wobec rozwoju biotechnologii, ed. L. Kondratiewa-Bryzik, K. Sękowska-Kozłowska, Warszawa 2013.

Dickson v. the United Kingdom, no. 44362/04, judgment of 4 December 2007.

Foulon and Bouvet v. France, no. 9063/14 and 10410/14, judgment of 21 July 2016.

Paradiso and Campanelli v. Italy, no. 25358/12, judgment of 27 January 2015. 
Glass v. the United Kingdom, no. 61827/00, judgment of 9 March 2004. M.A.K. and R.K. v. the United Kingdom, no. 45901/05 and 40146/06, judgment of 23 March 2010.

S. and Marper v. United Kingdom, no. 30562/04 and 30566/04, judgement of 4 December 2008.

Nowicki M.A., Wokół Konwencji Europejskiej. Komentarz do Europejskiej Konwencji Praw Człowieka, Warszawa 2017.

Van derVeldenv. Netherlands, no. 29514/05, decision of 7 December2006.

S. and Marper v. United Kingdom, no. 30562/04 and 30566/04, judgement of 4 December 2008.

Halford v. United Kingdom, no. 20605/92, judgement of 25 June 1997.

Phinikaridou v. Cyprus, no. 23890/02, judgment of 20 December 2007.

Tyrer v. United Kingdom, no. 5856/72, judgement of 2 April 1978, § 73.

Marckx v. Belgium, no. 6833/74, judgement of 13 June 1979.

Keegan v. Ireland, no. 16969/90, Judgement of 26 May 1994.

Golder v. United Kingdom, no. 4451/70, judgement of 21 February 1975.

Weber and Saravia v. Germany, no. 54934/00, decision of 29 June 2006.

S.H and Others v. Austria, no. 57813/00, judgment of 3 November 2011.

Draon v. France, no. 1513/03, judgment of 6 October 2005.

D. v. Ireland, no. 26499/02, decision of 27 June 2006.

Jalloh v. Germany, no. 54810/00, judgment of 11 July 2006.

Jäggi v. Switzerland, no. 58757/00, judgment of 13 July 2006.

Tysiąc v. Poland, no. 5410/03, judgment of 20 March 2007.

Darmon v. Poland, no. 7802/05, decision of 17 November 2009.

Gronmark v. Finland, no. 17038/04, judgment of 6 July 2010.

Backlund v. Finland, no. 36498/05, judgment of 6 July 2010.

Koch v Germany, no. 497/09, judgment of 19 July 2012.

Mennesson v. France, no. 65192/11, judgment of 26 June 2014.

Labassee v. France, no. 65941/11, judgment of 26 June 2014.

D. and Others v. Belgium, no. 29176/13, decision of 8 July 2014.

Gross v. Switzerland, no. 67810/10, judgment of 30 September 2014.

Y.Y. v. Turkey, no. 14793/08, judgment of 10 March 2015. 
Evans v. the United Kingdom, no. 6339/05, judgment of 10 April 2007. Handyside v. United Kingdom, no. 5493/72, judgement of 7 December 1976. Merger and Cros v. France, no. 68864/01, judgement of 22 December 2004.

Convention for the Protection of Human Rights and Dignity of the Human Being with regard to the Application of Biology and Medicine adopted by the Committee of Ministers of the Council of Europe on 19 November 1996, CETS no.164.

Convention for the Protection of Human Rights and Fundamental Freedoms adopted 4 November 1950, ETS 5, 213 UNTS 222.

Directive 95/46/EC of 24 October 1995 on the protection of individuals with regard to the processing of personal data and on the free movement of such data provides that the object of national laws on the processing of personal data, Official Journal L 281, 23/11/1995 P. 0031-0050.

Police and Criminal Evidence Act 1984, 1984 c. 60.

R. v. R.C., [2005] 3 S.C.R. 99, 2005 SCC 61.

Recommendation no. R (87) 15 of the Committee of Ministers regulating the use of personal data in the police sector.

Recommendation no. R (92) 1 of the Committee of Ministers on the use of analysis of deoxyribonucleic acid DNA within the framework of the criminal justice system.

The Council of Europe Convention of 1981 for the protection of individuals with regard to automatic processing of personal data, ETS no. 108, 28.01.1981.

The International Declaration on Human Genetic Data, adopted by the General Conference of UNESCO on 16 October 2003, SHS/EST/BIO/06/1. The Universal Declaration on the Human Genome and Human Rights adopted by the General Assembly on the 11th Of November 1997, A/ Res/53/152.

United Nations Convention on the Rights of the Child of 1989, United Nations Treaty Series, vol. 1577. 


\section{SUMMARY}

\section{European Court of Human Rights Case Law on Genetic Information in the Scope of International Biomedical Law}

The aim of the study is to analyze the case law of the European Court of Human Rights on genetic information in the scope of international biomedical law, as expressed in the International Declaration on Human Genetic Data and the Convention on the Protection of Human Rights and Human Dignity in the Field of Application of Biology and Medicine. The Court held that the genetic information is protected under the law of the Convention on Human Rights and Fundamental Freedoms. The model of the right to respect for private life is reflected in its shape, as the Court noted in the Van der Velden v. The Netherlands and S. and Marper v. The United Kingdom cases. It leads to the conclusion that the provision of Article 8 of the Convention provides the protection of genetic information, subject to certain restrictions that are "in accordance with law" and "necessary in a democratic society". Such conclusion is in compliance with art. 12, art. 17 (b) art. 21 (c) of the International Declaration on Human Genetic Data, and art. 11 of the Convention for the Protection of Human Rights and Dignity of the Human Being with regard to the Application of Biology and Medicine.

Keywords: genetic data protection, the right to respect for private life, international biomedical law, European Court of Human Rights case law.

Paweł Kwiatkowski, University of Gdańsk, Faculty of Law and Administration, Bażyńskiego 6, Gdańsk 80-309, Republic of Poland, e-mail: pawel.kwiatkowski@prawo.ug.edu.pl.

DOI 10.14746/ppuam.2020.11.07 
